Pamiętnik Literacki 2019, 4, s. 149-159

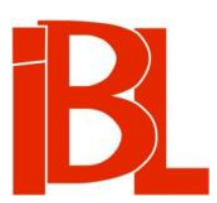

\title{
Retoryki wodzostwa. Kilka uwag o pewnych przypadkach wypowiedzi przywódczych
}

Zbigniew Kloch 
Pamiętnik Literacki CX, 2019, z. 4, PL ISSN 0031-0514

DOI: $10.18318 / \mathrm{pl} .2019 .4 .10$

ZBIGNIEW KLOCH Uniwersytet Warszawski

\section{RETORYKI WODZOSTWA KILKA UWAG O PEWNYCH PRZYPADKACH WYPOWIEDZI PRZYWÓDCZYCH}

Mówienie układa się w rozpoznawalne gatunki. Wiedzieli o tym i Michaił Bachtin, dla którego wypowiedź nie istnieje w zasadzie poza schematem sytuacyjnym, jakiego się wraz z mową uczymy, i Anna Wierzbicka, która w ślad za Bachtinem próbowała stworzyć koncepcje „genrów mowy” ${ }^{1}$. Jej nazewnictwo raczej się nie przyjęło, co nie zmienia faktu, że zasady funkcjonowania mowy w sytuacjach wypowiedzeniowych sformułowane przez Bachtina i Wierzbicką sa nadal aktualne. Trwaja, pomimo zmieniających się co pewien czas koncepcji opisu języka. Mówiąc z chęci lub z konieczności, realizujemy jakieś konwencje wypowiedzeniowe. Świadomość potoczna rozróżnia - intuicyjnie, ale myślę, że dość precyzyjnie - ekwiwalenty gatunkowe stylów mówienia, z którymi sa zgodne takie np. określenia: „mówisz jak ksiądz”, „mówisz jak belfer”, „polityk”, „menel”, ,prostytutka”, ,pisowiec”, „faszysta”. Nasuwa się jednak pytanie: czy mamy prawo tego typu klasyfikacje dowolnie rozszerzać na style charakterystyczne dla grup, które swe wypowiedzi kształtują zgodnie $z$ pewną matrycą stylistyczną, uzależnioną od celów ideologicznych? Odpowiemy twierdząco, jeśli styl i inne właściwości tekstu traktowane sa jako wyznaczniki pewnej historycznie określonej retoryki, powiązanej z konkretną ideologią. Ale na postawione pytanie można też odpowiedzieć przecząco - jeśli chcielibyśmy zasugerować, że istnieje jakiś uniwersalny wzorzec nawiazujący do ideologii faszyzmu czy marksizmu. Mówienie zideologizowane krąży wokół typowych dla siebie tematów i, zwykle, podobnych celów wypowiedzi: perswazyjnych, propagandowych. Jednakże zazwyczaj w takich przypadkach celowo modyfikuje się w zależności od sytuacji gatunkowe właściwości wypowiedzi. W tym miejscu chciałbym sprawdzić zasadność postawionej tezy w stosunku do wypowiedzi, które realizują wzorzec retoryki wodzowskiej, wypowiedzi przywódcy, w jej dawniejszych i dzisiejszych postaciach.

Trzeba więc ustalić, jak mówi lub powinien mówić przywódca?

Wódz jest tym, który prowadzi, zatem kimś, kto wie, dokąd należy podążać, zna kierunek i drogę. Wódz zwykle nie ma w tej kwestii wątpliwości, a przynajmniej ich publicznie nie wyraża. Zna rozwiązania, argumentuje na ich rzecz, a retoryka takiej argumentacji ma pozyskać niezdecydowanych, oponentów zaś porazić. Wódz wie, że po jego stronie jest prawda i że jest w jej posiadaniu, podczas gdy inni przeważ-

1 A. Wi erzbicka, Genry mowy. W zb.: Tekst i zdanie. Zbiór studiów. Red. T. Dobrzyń ska, E. Janu s. Warszawa 1983, s. 131. 
nie się mylą. Wódz raczej nie dyskutuje, lecz stwierdza, określa kierunki działania, jakie tych, którzy go słuchaja, niechybnie doprowadzą do celu.

Ekspresja semiotyczna przywódcy jest podwójnie uwikłana kulturowo. $Z$ jednej strony, realizuje pewien jego obraz bądź stereotyp, ale też ma charakter indywidualny, związany z osobowością lidera i doraźnymi celami mowy, które mają być urzeczywistnione. Wystapienie publiczne jest w większym lub mniejszym stopniu spektaklem, jest steatralizowane - w Goffmanowskim rozumieniu terminu. Hitler w swych ważniejszych wystapieniach posiłkował się ekspresyjna gestykulacją, skandował słowa, posuwał się do krzyku, co zostało sparodiowane przez Chaplina w filmie Dyktator z 1940 roku. Retoryka nazizmu w ogóle była teatralnie krzykliwa, jak stwierdził Victor Klemperer w swoim Notatniku filologa. Być może ekspresyjność Führera należałoby interpretować w odniesieniu do kultu ciała i tężyzny fizycznej, który panował w czasach nazizmu. Ruch, przesadna gestykulacja, krzyk - zwielokrotniaja i intensyfikują wyjątkowość wypowiadanych słów, a przywódca zabiera przecież publicznie głos tylko na niepowszednie tematy. Stylistyka tego rodzaju nie przenosiła się jednak w czasach nazizmu na teksty pisane. Victor Klemperer zauważa:

Można by przypuszczać, że LTI [tj. Lingua Tertii Imperii - język Trzeciej Rzeszy], która jest przecież w swojej istocie retoryczna i nieustannie zwraca się do uczucia, powinna, podobnie jak czasy „burzy i naporu", hołdować wykrzyknikowi. Tymczasem wcale nie jest to uderzające; przeciwnie, zdaje się ona posługiwać tym znakiem dosyć oszczędnie. Wygląda na to, iż wszystko w niej jest w sposób tak oczywisty zawołaniem i wykrzyknieniem, że nie potrzebuje ona do tego celu specjalnego znaku interpunkcyjnego $[\ldots]^{2}$.

W porównaniu $z$ Hitlerem - Stalin przemawiał w sposób dość stonowany, można więc zaryzykować stwierdzenie, że nawet dyktator nie musi w swoich wystąpieniach realizować tego samego wzorca wypowiedzeniowego, choć wypowiedzi tyranów zwykle w pewnym stopniu się do siebie upodobniają. Także przywódców autorytarnych. Semiotyka tego rodzaju przemówień łączy się z teatralizacją, która jest efektem stereotypowych przekonań o tym, jaki kształt mieć powinno ważne publiczne wystapienie. Wódz nie zabiera zwykle głosu w sprawach błahych. Ekspresja ruchu, gesty, intonacja, akcentuacja słów mają potwierdzać przekonanie, że oto mówi człowiek wyjątkowy, zdecydowany, świadom celów wypowiedzi i ich konsekwencji. Wódz w stanie silnych emocji ma prawo krzyczeć, przekraczać konwencjonalne reguły sytuacyjne. Przykładem mogą tu być przemówienia Władysława Gomułki, w swoim czasie (1956-1970) pierwszego sekretarza PZPR, i jego „uderzanie butem w mównicę”, co stało się po latach składnikiem stereotypu obrazu ówczesnego sekretarza partii. Lub - współcześnie - wystapienie sejmowe Jarosława Kaczyńskiego o „mordach zdradzieckich” ludzi odpowiedzialnych za śmierć jego brata w katastrofie smoleńskiej. Przekonanie, że mowa jest znacznikiem stanu psychicznego wypowiadającego się, sformułowane dawno, bo w 1927 roku, przez Edwarda Sapira, należy dziś do dobrze ugruntowanych w świadomości potocznej ${ }^{3}$. Ale gest, intonacja, rozłożenie akcentów w wypowiedzi, choć przekładają się na semiotyczne oznaki stylu tego, kto mówi, to nie zawsze są prostym przekła-

2 V. Klem pere r, LTI. Notatnik filologa. Przeł., oprac. J. Zy c h ow ic z. Warszawa 1989, s. 82.

3 E. Sa pir, Mowajako rys osobowości. W: Kultura, język, osobowość. Wybrane eseje. Przeł. B. S tanosz. R. Zimand. Wstęp A. Wierzbicka. Warszawa 1978. 
dem cech jego osobowości na styl wypowiedzi. Wypowiedź wydaje się częściej kulturowym obrazem roli społecznej osoby mówiącej niż bezpośrednią i wyrażaną w prosty sposób oznaka jej cech. Jest z pewnością obrazem lidera budowanym poprzez wypowiedzi, które tworza jego wizerunek w świadomości społecznej. Wizerunek lidera bywa utożsamiany $z$ wizerunkiem partii lub też, w przypadku przywództwa biznesowego, $z$ obrazem firmy. Mowa jest osadzona w kontekście sytuacyjnym, zatem obraz przywódcy musi się zmieniać, tak jak zmieniają się sytuacje, choć wcale diametralnie zmieniać się nie musi stylistyka jego przemówień. Jakkolwiek z pewnością mało odkrywcze, stwierdzenie to pozostaje trwale prawdziwe. Można w tym miejscu przywołać mowę Hitlera w dniu napaści Niemiec na Polskę i jego ostatnie radiowe przemówienie, wygłoszone na krótko przed kapitulacją III Rzeszy ${ }^{4}$. Wódz stara się zachować swój wizerunek w każdej sytuacji. W obu wystąpieniach pojawiają się podobne motywy, choć ich funkcja zmienia się wraz z sytuacją historyczną.

Język stanowi obraz świata, którego kształt konstruowany jest przez „ja” wpisane w wypowiedź i w sytuację wypowiadania, a zatem w określone „tu” i „teraz”. Jak np. w przemówieniu papieża Jana Pawła II na Placu Zwycięstwa w Warszawie 2 czerwca 1979, gdy homilię zakończyło wezwanie Ducha Świętego („Niech zstapi Duch Twój! I odnowi oblicze ziemi!”), ze słynnym dopowiedzeniem: „Tej Ziemi!”5. Wystapienie papieża zostało w ten sposób trwale związane $z$ określonym miejscem i określonym momentem. Mowa jako realizowany w czasie rzeczywistym akt wypowiedzi buduje obraz wypowiadającego w sytuacyjnym uwikłaniu komunikacyjnym. Papież Benedykt XVI w swoim wystąpieniu w Auschwitz-Birkenau przemawiał jako głowa Kościoła i jako przedstawiciel narodu, który budował w Europie obozy koncentracyjne:

Mówić w tym miejscu kaźni i niezliczonych zbrodni przeciwko Bogu i człowiekowi, nie mających sobie równych w historii, jest rzeczą prawie niemożliwą - a szczególnie trudną i przygnębiającą dla chrześcijanina, dla papieża, który pochodzi z Niemiec ${ }^{6}$.

Jak uważa Maria Wiśniewska, przywództwo ma charakter procesualny, zatem jest raczej procesem niż stanem, zarówno w przypadku wielkich osobowości politycznych, czy szerzej: historycznych, jak i liderów instytucji różnego rodzaju. Jest zjawiskiem społecznym, a więc powiązanym ze zmieniającymi się normami kultury i z opisanym m.in. przez Ervinga Goffmana zjawiskiem teatralizacji ${ }^{7}$. Godząc się

4 Zob. Wielkie mowy historii. Red. W. Władyka, P. Zmelonek, T. Zaw a d zki. T. 3: Od Hitlera do Eisenhowera. Wybór, oprac. T. Zawadzki. Koment. E. Bendyk [i in.]. Przeł. J. Bokłaż e c [i in.]. Warszawa 2006, s. 47-61, 172-196.

5 Ibidem, t. 4: Od Kennedy'ego do Ratzingera (Wybór, oprac. T. Zaw a d z ki. Koment. E. B e n d y k [i in.]. Przeł. D. Bartmann [i in.]), s. 181.

$6 \quad$ Przemówienie Benedykta XVI podczas wizyty $w$ obozie koncentracyjnym Auschwitz-Birkenau. Oświęcim 28 V 2006. „Tygodnik Powszechny” 2006, nr 23, s. 16. Wystąpienie Benedykta XVI szczegółowo analizowałem w pracy Kultura doświadczenia potocznego. Semiotyczne aspekty codzienności. Eseje (Warszawa 2014, s. 67-81).

$7 \quad$ E. G offm a n, Człowiekw teatrze życia codziennego. Przeł. H. D a tn e r-Ś pi e w a k, P. Śpi ew a k. Wstęp J. Sza cki. Warszawa 1977. - M. Wiśn iew s ka, Spektakl przywództwa w oczach socjologa. „Przegląd Humanistyczny” 2015, nr 3. (Z pracy tej zapożyczyłem koncepcję procesualnego 
na wybór swojej roli, przywódca podczas publicznego wystapienia jest w zasadzie cały czas na scenie, dostosowuje więc swoje gesty i słowa do sytuacji.

Przywódca mówi publicznie w określonych okolicznościach, które w znacznym stopniu modeluja konstrukcje jego wypowiedzi w planie stylistycznym, czy szerzej retorycznym. A te parametry są pochodną zakładanych celów. Jest to jedna z zasad budowania wypowiedzi, znana retorom antycznym i greckim. Zasada obowiązująca przez wieki, bez względu na to, czy mamy do czynienia $z$ wystapieniem tyrana, głowy Kościoła, czy szefa korporacji, który przemawia do stosunkowo małej grupy podwładnych. Wypowiedź przywódcy musi zatem łączyć się z czasem i miejscem poprzez użycie kategorii języka, które lingwiści oznaczają za pomoca określeń "deixis” i „shifters”. Sytuacyjne uwikłanie wypowiedzi sprawia, iż - jak wiadomo z tradycyjnych zasad retoryki - mowa powinna być tak zbudowana, aby słowa pomiędzy mówiącym a słuchającymi wytwarzały rodzaj wspólnoty, prowadziły do porozumienia. Hitler w swych przemówieniach odwoływał się do kategorii rasy i przestrzeni życiowej, Gomułka do wspólnoty mas pracujących, Jan Paweł II do wspólnoty tworzonej przez wiarę, a szef korporacji odwołuje się do wspólnoty celów i misji instytucji, którą zarządza. Ciekawym przykładem budowania wspólnoty komunikacyjnej może być przemówienie Johna F. Kennedy'ego wygłoszone przy murze berlińskim w czerwcu 1963, gdy to ówczesny prezydent Stanów Zjednoczonych powiedział:

Dwa tysiące lat temu najbardziej dumne słowa brzmiały: Civis Romanus sum. Dzisiaj, w świecie wolności, z największą dumą mówimy: Ich bin ein Berliner ${ }^{9}$.

Wystapienie przywódcy jest zwykle w mniejszym lub większym stopniu zideologizowane, i to zarówno w odniesieniu do waskiego pojmowania ideologii, jako związku wypowiedzi z doktryną polityczną, jak też w rozumieniu szerokim, uwzględniającym operowanie kategoriami pewnego rodzaju dyskursu ${ }^{10}$. I jeszcze jedna właściwość tego typu sytuacji komunikacyjnych: od przywódcy oczekuje się, że powie coś wyjątkowego, co będzie miało wpływ na rzeczywistość.

Przywódca zazwyczaj przemawia dość często, m.in. dlatego, że chce podtrzymywać swój wizerunek. W czasach wolnych mediów ten wizerunek kreują w dużym stopniu środki masowego przekazu: prasa, telewizja, Internet. Jest oczywiste, że nie każde wystapienie wodzowskie trafia do repertuaru wielkich mów historii. Nie wszystkie $z$ nich mają przecież tę samą wartość. $\mathrm{W}$ dodatku są realizacją różnych konwencji gatunkowych. Mówienie przywódcy to raczej speech, a nie talk, raczej discours niż récit. Wódz zwykle się wypowiada (co podkreśla żargonowe określenie dziennikarskie „pozyskać wypowiedź polityka dużego formatu”), domena jego mowy jest bowiem wypowiedź ustna, wtórnie przedrukowywana, przede wszystkim utrwa-

charakteru przywództwa i jego związku z teorią Goffmana.) Zob. też M. W i śn i e w s ka, Anatomia przywództwa charyzmatycznego. Ujęcie socjologiczne. Kraków (w druku).

8 Zob. R. J a k o b s o n, Szyftery, kategorie czasownikowe i czasownik rosyjski. W: W poszukiwaniu istoty języka. Wybór pism. Wybór, wstęp M. R. M a y e n ow a. T. 1. Warszawa 1989 (przeł. E. J anus).

9 Wielkie mowy historii, t. 4, s. 38.

10 Zob. T. Eaglet o n, Ideology: An Introduction. London - New York 1991. 
lana w telewizji, w radiu, w Internecie. Warto w tym miejscu przypomnieć fakty, jak się może wydawać, oczywiste. Po pierwsze, przywódca mówiąc, popełnia błędy, przejęzyczenia (Kaczyński: „I żadne krzyki i płacze nas nie przekonaja, że białe jest białe, a czarne jest czarne”; „My jesteśmy tu, gdzie wtedy, oni tam, gdzie stało ZOMO"11), które natychmiast podchwytują i eksponują media oraz polityczni konkurenci. Wódz co pewien czas powinien się pokazywać publicznie i wygłaszać przemówienia, a więc mówić - nawet wówczas, gdy ma przed sobą tekst wcześniej przygotowany. Semiotyczne konwencje dzisiejszej kultury sprawiają, że w demokracji należy mówić w zasadzie „bez kartki”, co stoi w opozycji do zwyczajów komunikowania publicznego z czasów PRL, gdy wystąienia przede wszystkim czytano. Demokracja, w takiej czy innej postaci, otwiera przestrzeń dla wolności wypowiedzi i spontanicznego mówienia. Po drugie, i stanowi to konsekwencje pierwszego, wypowiedzi wodzowskie zdominowane sa przez gatunki i formy oralne, przede wszystkim o charakterze monologowym, chyba że mamy do czynienia z wywiadem, który zawiera elementy autentycznego dialogu. Charakterystyczne cechy wypowiedzi oralnej, takie jak intonacja, siła i barwa głosu, tempo mówienia, interwały iloczasowe w znacznym stopniu kreują wizerunek przywódcy, lecz te właściwości trzeba także zaliczyć do cech stylu mówienia osoby, choć niektóre $z$ nich traktowane być moga jako elementy ogólnego obrazu polityka w roli przywódcy. Wódz powinien mówić zatem w sposób zdecydowany, aby można było odnieść wrażenie, że świetnie czuje się w obranej roli, że góruje nad audytorium.

Gatunki wypowiedzi przywódczej to przede wszystkim orędzie, przemówienie, wystapienie. To gatunki silnie sformalizowane, związane $z$ rolą i pozycja osoby. Orędzia wygłaszają prezydenci, premierzy, papieże (Urbi et Orbi), ale nie działacze związkowi czy liderzy znaczacych instytucji. Sa to wystapienia o bardzo szerokim adresie społecznym, ważne ze względu na temat i konieczność podtrzymywania poczucia wspólnoty, realizujące zazwyczaj podobny repertuar aktów mowy (przekonywanie, nakłanianie, propagowanie idei, grożenie, wyznaczanie celów). Zarówno polityk, jak i lider młodocianego gangu powinien być w oczekiwaniu społecznym „człowiekiem wymownym”, posiadającym umiejętność świetnego posługiwania się słowami. Kształt konkretnej wypowiedzi zależy od konwencji komunikacyjnych, $\mathrm{w}$ których jest ona realizowana, co określają wyznaczniki gatunku i oczekiwanie, że przywódca powinien sobie zawsze radzić z sytuacyjnym użyciem języka lub slangu. Ten typ kulturowych oczekiwań wydaje się silnie związany z rolą lidera. Anna Wierzbicka (za Williamem Labovem i Rogerem D. Abrahamsem) podaje ciekawy przykład gatunku „sytuacyjnych obelg” używanych w amerykańskim angielskim przez młodych czarnoskórych - chodzi o tzw. gatunek dozens (tuzin), w Black English, który jest pewną forma „mowy ulicznej”, opartą na dowcipie i żonglerce słownej. Ta zaś „polega na łamaniu reguł i konwencji "przyzwoitego" społeczeństwa" ${ }^{12}$. Styl mówienia nadaje tożsamość przywódcy i w dużym stopniu kreuje go jako lidera. W tym miejscu warto może odwołać się do licznych opracowań na temat

11 R. Zimny, P. Nowak, Słownik polszczyzny politycznej po roku 1989. Warszawa 2009, s. 61, 254.

12 A. Wierzbicka, Język - umyst - kultura. Wybór pod red. J. Bartmińskieg o. Warszawa 1999, s. 258-260. Tam też znajdują się odniesienia do prac W. Labova i R. D. Abrahamsa. 
„języka Wałęsy” ${ }^{13}$ i przekonań niektórych publicystów (głównie prawicowych) na temat umiejętności retorycznych Jarosława Kaczyńskiego.

Tak czy inaczej, mówienie przywódcy najczęściej realizowane jest za pomocą różnych gatunków wypowiedzi okolicznościowych. Ten kontekst okolicznościowy można sprowadzić do repertuaru powtarzalnych sytuacji społecznych, kulturowych, które generowane sa przez aktualne konteksty polityczne. Wódz przemawia najczęściej w sytuacjach i o sprawach wymagających wyrażenia istotnej, wiążącej opinii. Takiej, która odnosi się do aktualnego stanu gospodarki państwa czy aktualnych kryzysów społecznych. Nie w każdym z możliwych przypadków musi to być mowa skierowana do całego narodu. Jej ważność semantyczną określa bowiem właśnie sytuacja, okoliczności, w jakich odbywa się wystapienie przywódcy. Przywódca przemawia także w sytuacjach typowych, zabiera głos na posiedzeniach sejmu, udziela wywiadów, odpowiada (a przynajmniej powinien) na pytania dziennikarzy. Ów zestaw możliwych wypowiedzi nazwałbym „przywódczym mówieniem rutynowym". W tych przypadkach semiotyczną wartość wystąpień podnosi to, co się w wypowiedziach pojawi i jak w przyszłości będą one interpretowane. Myślę tu o takich wypowiedziach, które albo przechodzą do repertuaru mów historycznych, albo pozostają na długo w lokalnej świadomości kulturowej, politycznej, jak cytowany zwrot z przemówienia Kennedy'ego w Berlinie czy ten rozpoczynający przemówienie Wałęsy w parlamencie amerykańskim („My, Naród”) lub też ostatnie jako szefa rządu przemówienie sejmowe Jana Olszewskiego z powtarzanym wielokrotnie pytaniem o to, jaka ma być przyszła Polska.

W dzisiejszej kulturze politycznej rolę przekaźnika myśli i komentatora słów przywódcy pełni bardzo często jego rzecznik prasowy, czy ściślej - rzecznik prasowy urzędu, instytucji społecznej, politycznej. Rzecznik jest porte-parole tego, w którego imieniu się wypowiada. To pojęcie w odniesieniu do literatury określa osobę mówiącą, którą można identyfikować $\mathrm{z}$ autorem ze względu na pewne wskaźniki semiotyczne, dające się zauważyć w porządku tekstowym. W odniesieniu do zasad dyskursu obowiązujących obecnie w życiu publicznym, rzecznik, porte-parole, wypowiada się $z$ czyjegoś upoważnienia, reprezentuje poglądy przywódcy lub instytucji. Rzecznik prasowy jest zatem nośnikiem cudzego słowa, choć przedstawiając punkt widzenia osoby, w której imieniu występuje, zachowuje swój styl i nie musi koniecznie posługiwać się mową pozornie zależną. W pewnych przypadkach rzecznik „prostuje" wypowiedzi przywódcy, wyjaśnia, co ten miał na myśli, interpretuje jego słowa. Jest to dość częsta praktyka w polskim życiu politycznym ostatnich lat. Można więc przyjąc, że odpowiednio ważny przywódca ma zwykle swojego „dublera”, który (w dzisiejszej kulturze i typowych dla niej zwyczajach komunikacyjnych) przejmuje część jego kompetencji werbalnych. A to - w sensie semiotycznym, zatem także symbolicznym - podnosi rangę wypowiedzi wodzowskich poprzez ograniczenie ich częstotliwości do sytuacji niezwykle ważnych, kiedy wódz wypowiada się sam. Rzecznik prasowy ma również chronić przywódcę przed atakami wścibskich i aroganckich dziennikarzy, jest więc jego swoistą tarczą. Instytucja rzecznika odwzorowuje w pewnym stopniu hierarchiczny porządek władzy.

13 Zob. J. Bralczy k, Ojęzyku Wałęsy. W: Ojęzyku polskiej polityki lat osiemdziesiatych i dziewięćdziesiatych. Warszawa 2003. 
Rzecznik prasowy, który reprezentuje firmę lub korporację, pełni w zasadzie te same funkcje co porte-parole instytucji politycznej. Lider korporacji mówi zazwyczaj publicznie dużo rzadziej niż przywódca polityczny, choć także w sytuacjach raczej, powiem $z$ pewna przesada - wyjątkowych. Jest znacznie mniej widoczny publicznie niż polityczni przywódcy. Kontaktuje się zwykle $z$ bezpośrednimi podwładnymi, którzy przekazują informacje do pracowników sobie podległych. Publicznie występuje najczęściej okazjonalnie, gdyż sprawami public relations zajmuje się dobrze poinformowany rzecznik prasowy. Można zatem uznać, że w dzisiejszym komunikowaniu społecznym słowo przywódcy jest szczególnie nacechowane, skoro zarówno wysokiej rangi polityk, jak i szef ważnej firmy mają swoich przedstawicieli komunikujących się na co dzień ze społeczeństwem (lub społecznością). Warto w tym miejscu przypomnieć, że instytucja rzecznika prasowego pojawiła się pod koniec XIX wieku i rozwinięta została w wieku XX w związku $\mathrm{z}$ rolą propagandowa prasy i dostępnych wtedy środków masowego przekazu. Warto także pamiętać, że konwencje wypowiedzi wodzowskiej od tamtego czasu uległy istotnym przemianom. Hitler w swoich przemówieniach krzyczał, wystapienia Gomułki były pełne oralnych znaczników ekspresji emocji, podczas gdy dzisiejsze oczekiwania wobec wypowiedzi wodzowskiej sprawiają, że powinny być one raczej stonowane.

I takie też najczęściej są, oczywiście poza licznymi przypadkami wystąpień sejmowych, które owej zasadzie przeczą. Przykłady tego rodzaju znaleźć można nie tylko w polskim parlamentaryzmie. Badacze intonacyjnych przebiegów wypowiedzi są zgodni: prozodia języka pełni funkcje syntaktyczne i semantyczne; rytm, melodia zdania, akcent logiczny, który nie musi się pokrywać z typowym sposobem akcentowania wyrazów, zgodnym z systemem języka etnicznego - to wszystko służy ekspresji emocji wypowiadającego się i jest werbalnym znacznikiem cech jego osobowości ${ }^{14}$. Dźwiękowy kontur wypowiedzi konstruuje w dużym stopniu obraz mówiącego. Trudno zdecydowanie stwierdzić, czy realizowany w wypowiedzi prozodyjny porządek mowy przywódczej jest silniej związany z cechami osobowości mówiącego, czy z kulturowymi wyznacznikami ekspresji werbalnej, które określają konwencje tego gatunku. Bez wątpienia nie jest zdeterminowany tylko i wyłącznie typem władzy; wystarczy porównać przemówienia przywódców ekstremalnych totalitaryzmów, Hitlera i Stalina. $Z$ pewnością sposób publicznego mówienia przywódcy skorelowany jest jednak w jakimś stopniu $\mathrm{z}$ obowiązującym lub deklarowanym modelem kultury politycznej, w której ramach wypowiedź jest realizowana. W demokracji nie eksponuje się zwykle siły głosu, lecz siłę argumentów. Przywódca ma być sugestywny przede wszystkim za sprawą merytorycznych, a więc semantycznych, wyznaczników swojej wypowiedzi, wizji i dążeń, które ma zamiar zrealizować.

Reguły dzisiejszej kultury publicznego wypowiadania się sprawiają, że na pierwszy rzut oka dwaj główni przywódcy polskiej sceny politycznej z pozoru mówią podobnie. Bliższa analiza ujawnia jednak istotne różnice. Donald Tusk używa za-

14 Zob. M. Dłu s ka, Prozodia języka polskiego. Kraków 1947. - D. C i s e k, Z zagadnień intonacji języka polskiego i jej funkcji. „Zeszyty Naukowe Wyższej Szkoły Pedagogicznej w Bydgoszczy. Studia Filologiczne” 1975, z. 2. - J. Bl o c h, Wspólna sprawa, wspólny patos - o intonacji wystapień sejmowych. Na stronie: Bloch-J 9620Wspólna9620Sprawa9620wspolny9620patos9620(2)pdf (data dostępu: 28 II 2019). 
zwyczaj zdań prostych, przed słowami szczególnie istotnymi robi nico dłuższe pauzy. Niekiedy przyspiesza tok słów. Jego wypowiedzi (wystapienia oficjalne, a także wywiady) interpretować można jako podążające za myślą (wcześniejszymi przemyśleniami) lub jako poszukiwanie precyzyjnej odpowiedzi na zadane mu właśnie pytanie). Powiedziałbym, że temu sposobowi wypowiadania się można przypisać przekonanie, iż należy mówić możliwie prosto, aby być rozumianym i jak najbardziej sugestywnym. Rytm wypowiedzi jest tu zazwyczaj podporządkowany prozodii jezyka polskiego, w nieznacznym stopniu modulowany przez sytuację zewnętrzną. Jarosław Kaczyński posługuje się zwykle zdaniem rozbudowanym, często wielokrotnie złożonym. Chętnie wykorzystuje akcent zdaniowy zależnie od wagi tematu, jaki porusza, który to akcent zatem wiąże się z przedmiotem wypowiedzi, w mniejszym zaś stopniu z typowym profilem intonacyjnym zdania. Stosuje liczne dopowiedzenia i uściślenia, mające uprecyzyjniać wypowiedź. Ma wyraźne zamiłowanie do posługiwania się słowami obcego pochodzenia lub rzadko występującymi w polszczyźnie, takimi jak: „bifinlandyzacja Polski” (której dokonał Tusk), „landyzacja Polski”, „ojkofobia” 15 (oikofobia, z greckiego: strach przed domem, rodzina, własnym narodem), „dyfamacja”, ,zasada ordo caritatis”. W wypowiedziach Kaczyńskiego zawsze pojawiają się pewne słowa-hasła, jak „Polska”, „naród”, „ojczyzna”, „rodzina”. Można powiedzieć, że Kaczyński od lat mówi w ten sam sposób i przemawia takim samym językiem ${ }^{16}$. Użycie słów obcego pochodzenia ma niewątpliwie wskazywać na głęboką wiedzę mówcy, zdanie wielokrotnie złożone podkreśla logiczność użytych argumentów jako wcześniej dokładnie przemyślanych (logiczne wynikanie, wnioskowanie), wręcz oczywistych, których jednak nie potrafią zrozumieć polityczni oponenci. W wystapieniach adresowanych przede wszystkim do własnego elektoratu lub w sytuacjach szczególnego wzburzenia emocjonalnego Kaczyński intonuje wypowiedź na granicy krzyku:

My chcemy jasno podkreślić: tu mówimy „nie”, a już w szczególności, jeśli chodzi o dzieci. Wara od naszych dzieci ${ }^{17}$.

Obaj politycy podczas ważniejszych wystąień publicznych gestykulują, Tusk

„Ojkofobii” sporo miejsca poświęcił M. Na piórkowski w książce Turbopatriotyzm (Wołowiec 2019, s. 56-88).

16 Zob. A. Jakubowska, Język wypowiedzi publicznych Jarosława Kaczyńskiego w latach 2007-2010. „Refleksje” 2011, nr 3. Na stronie: http://hdl.handle.net/10593/3825/3825 (data dostępu: 28 II 2019). Przy analizie przemówień Tuska i Kaczyńskiego korzystam m.in. z internetowych zapisów wystąpień sejmowych tych polityków: www.youtube.com/watch?v=ehhf_ebowul; www.youtbe.com?watch/v=fYcVL_CLxRU; www.tvn24.pl/tusk-o-podzialach-w-polskiej-polityce-ispoleczenstwie,873948,s.html (data dostępu: 27 II 2019).

17 Na stronie: http://fakty.interia.pl/polka/news-kaczynski-wara-od-naszych-dzieci.nld.2887373 (data dostępu: 16 III 2019). Dodam, że ta niedawna wypowiedź Kaczyńskiego była szeroko komentowana w prasie i w innych mediach. Zob. Nie ma wspólnoty, łaczy nas tylko panika. Z M. Łuczewskim i M. Bilewiczem rozmawia G. Wys ocki. „Wyborcza.pl. Magazyn Świąteczny” 2019, nr z 13-14 IV. Bilewicz potraktował słowa Kaczyńskiego jako „okrzyk pogromowy”. Moim zdaniem, ten typ formuł-haseł może co najwyżej pełnić taką funkcje w sprzyjającej sytuacji, lecz w przypadku wystapienia Kaczyńskiego takim okrzykiem jeszcze nie jest. Na temat funkcji tego rodzaju zawołań zob. J. To k a r s k a - B a k i r, Okrzyki pogromowe. Szkice z antropologii historycznej Polski lat 1939-1946. Wołowiec 2012. 
zwykle akcentuje rytm wypowiedzi prawą ręką, Kaczyński obiema rękami, często z gestem ich rozchylania i przybliżania. Obaj w wystapieniach publicznych chętnie posługują się figurą ironii, kierowaną wobec słów swoich przeciwników lub ich konkretnych stwierdzeń. Zasadnicza różnica między wystąpieniami tych polityków przejawia się przede wszystkim w odniesieniach ideologicznych wypowiedzi (znów mam na myśli ideologię rozumianą szeroko, nie tylko odniesienia do konkretnych przekonań politycznych) oraz w przywiązaniu do tworzenia pewnego rodzaju matryc komunikacyjnych lub w braku występowania takiej tendencji.

W swoich licznych i znanych analizach nowomowy i sposobu mówienia przedstawicieli władzy z czasów PRL Michał Głowiński wskazał wyraźne podobieństwa nazwę to tak - „mówienia obozu PiS”, w tym wystąpień Kaczyńskiego, do języka propagandy z lat komunizmu. Przede wszystkim w planie budowania obrazu świata, konstruowania wizerunku wroga i ujednolicania przekazów słownych w ogólności ${ }^{18}$.

Wróg może przybierać różne postaci: raz jest to „uchodźca, zagrażający naszej kulturze i jej podstawowym wartościom”, innym razem „całkowite niezrozumienie miejsca Polski w Europie i jej reformatorskich działań”, jeszcze innym - „lewactwo” i LGBT. Przemówienia przywódcy politycznego utrzymane są zwykle w takiej konwencji wypowiedzeniowej, którą nazwać można nadrzędną wobec samego aktu mowy. Głowiński pisał w odniesieniu do tego przypadku o swoistym gatunku wypowiedzi, jaki wypracowany został przez władze w czasach PRL - o wystapieniu dostojnika partyjnego. Określenie „wystapienie”, zamiast nazwy gatunkowej „przemówienie", sugerowało, że:

mowa takiej czy innej wysoko postawionej w hierarchii osoby jest nie tylko aktem werbalnym, [...] nie sprowadza się do zespołu użytych słów, [...] jest także - czynem (stylizacja teatralna, pochodna od „wystapić w teatrze”, wydaje mi się tu mniej istotna). Wystąpić to coś więcej, niż mówić. Wystapienie może mieć tylko, oczywiście, charakter oficjalny ${ }^{19}$.

Mowa jest w tym przypadku działaniem, oddziaływaniem i wzorcem stylu. Odnośnie do niedawnych wystąpień polskich polityków powiedzieć można, że Tusk zazwyczaj przemawia lub wypowiada się, Kaczyński zaś głosi wystąpienia (w określonym tu rozumieniu). Jego wypowiedzi, podobnie jak to było w czasach PRL, tworzą wzorce do naśladowania dla członków i zwolenników PIS, nie tyle w planie stylistyki, co merytorycznie. Efekty tego rodzaju praktyki wypowiedzeniowej wodza, w odniesieniu do propagandy komunistycznej, Głowiński nazwał „tekstami-matrycami" ${ }^{20}$. Mowa przywódcy stwarza więc pewien wzorzec wypowiedzi politycznej na określony temat, wyznacza partyjne strategie komunikacyjne, które kształtuja także konwencje stylistyczne. Okazuje się, że zwolennicy, akolici, sympatycy zaczynają mówić podobnie, czy nawet tak samo (te same formuły i zwroty, ten sam sposób argumentacji). Sądze jednak, że dzisiejsza propaganda i komunikowanie publiczne przebiega w dużo bardziej skomplikowanym układzie wytwarzania i prze- 
twarzania informacji, niż to miało miejsce w „,czasach słusznie minionych”, dlatego w odniesieniu do współczesności wolałbym mówić o „matrycowaniu informacji” lub „matrycowaniu komunikacyjnym” ${ }^{21}$, choć te kategorie obejmują też, oczywiście, „teksty-matryce” w rozumieniu Głowińskiego. W sytuacji istnienia wielu ośrodków komunikacyjnych nad tworzeniem propagandowych "tekstów-matryc” pracuja zwykle sztaby partyjne, lecz ich oddziaływanie nie obejmuje wszelkiej dostępnej przestrzeni komunikacyjnej. Na razie istnieje wiele możliwych sposobów mówienia o rzeczywistości, sposobów konkurencyjnych, także w planie ideologicznym, i komunikacja nie układa się w prosty opozycyjny wzór „oficjalne”-,prywatne”, dominujący w czasach PRL. I $z$ tych powodów „matrycowanie komunikacyjne” widziałbym jako rozbudowany proces, „teksty-matryce” - jako wypowiedzi tworzace wzorce w jednej możliwej postaci.

Wyjątkowość roli, która przypisuje sobie zazwyczaj przywódca, z czym wiąże sie tendencja do kształtowania własnego obrazu poprzez wystapienia oficjalne, sprawia, że w swoich wypowiedziach publicznych może on po prostu kłamać. Robił to z pewnością Hitler, nawet w ostatnim przemówieniu radiowym, robili to Stalin, Gomułka czy Fidel Castro. Kłamać - w podstawowym rozumieniu słowa lub w wersjach łagodnych: mijać się $\mathrm{z}$ prawda, przemilczać fakty, zawsze (z perspektywy mówiącego) w szlachetnym celu. Kłamstwo w różnorakiej postaci wydaje się istotnym elementem wypowiedzi przywódcy. Przywódca, przede wszystkim wódz autorytarny, pozwala sobie na wpisywanie w swoje wypowiedzi różnych odmian kłamstwa, to zaś nie ma prostych wyznaczników językowych, nie jest więc tak łatwe do weryfikacji, jak np. groźba lub prośba ${ }^{22}$. Przywódca autorytarny może kłamać, gdyż to on sam ustanawia prawa i reguły prawdziwości wypowiedzi, przywódca odwołujący się do zasad demokratycznych kłamać nie może, gdyż musi stosować się do wcześniej ustalonych zasad w danym porządku politycznym, a przynajmniej kłamać mu nie wypada. Pierwszy tworzy zatem „teksty-matryce”, drugi powinien wpisywać się $\mathrm{w}$ określone, zastane konwencje komunikacyjne. Sprawa podejrzeń wobec przywódcy, że mówi on nieprawdę lub dokonuje pewnych przemilczeń, wydaje się wpisana w porządek dzisiejszej komunikacji publicznej, gdzie funkcjonuje wiele niezależnych źródeł informacji, weryfikujących intencje mówiącego. W systemach totalitarnych, jeśli nawet podejrzewano wodza o kłamstwo, to takie przypuszczenia nie były publicznie weryfikowane. Przypadki tego rodzaju dokumentuje „notatnik filologa”, który ukazał się drukiem dopiero po upadku faszyzmu, czy „komentarze do słów” Głowińskiego „pisane do szuflady”. W społeczeństwach o swobodnym przepływie informacji wypowiedzi wodza sa nieustannie weryfikowane i podawane w wațliwość. Weryfikuje się to, co przywódca powiedział, i to, czego nie powiedział, a mógł pomyśleć ${ }^{23}$. Dzisiejszy przywódca jest więc poddawany presji „nieustanne-

Bardziej szczegółowo pisałem o matrycowaniu w pracy Mowa nienawiści i jej podstawowe odmiany. Aspekt komunikacyjny i semiotyczny (w zb.: O języku dla Anny Wierzbickiej. Red. nauk. J. Ch ojak, Z. Zaron. Warszawa 2018). 
go podejrzenia”, ciąłłej ocenie. Przemilczanie faktów wydaje się wpisane w gatunek wypowiedzi przywódczej, tak w jej wersji politycznej, jak i korporacyjnej.

Z poczynionych tu uwag można wyciągnąc szereg wniosków odnoszących się do wypowiedzi wodzowskiej. Po pierwsze, jest to gatunek użytkowy, silnie zakotwiczony sytuacyjnie, co wpływa zarówno na temat wypowiedzi, jak też, w pewnym stopniu, na jej wyznaczniki językowe i stylistyczne (prozodia, akcent zdaniowy, szybkość mówienia). Te są, $z$ jednej strony, domeną idiolektu mówiącego, $z$ drugiej zaś - odniesień do kultury politycznej, którą mówca reprezentuje, i strategii, jaką realizuje. Pomimo różnego rodzaju ekscesów w różnorakich parlamentach narodowych - najbardziej akceptowany wzorzec mowy przywódczej to dziś „strategia spokoju”. To, o czym wódz mówi najchętniej, skorelowane jest $z$ ideologia polityczną, którą realizuje. Wystarczy porównać przemówienia i wystąpienia Tuska i Kaczyńskiego; pierwszy akcentuje przede wszystkim wartości europejskie, drugi wartości charakterystyczne dla myślenia władzy prawicowej. Obaj często odwołuja się do poczucia wspólnoty, tyle że różnie rozumianej. Odniesienie do określonego systemu wartości jest zatem istotnym elementem wypowiedzi przywódcy. W przypadku mowy polityka są to zwykle wartości związane z państwem, narodem, rozwojem gospodarczym, w przypadku wypowiedzi lidera korporacji - wartości łączace się z rozwojem firmy. Po drugie, wypowiedzi przywódcze kreują wzorce politycznego mówienia, utrwalają pewien rodzaj argumentacji i sformułowań, jak też pewien typ strategii retorycznych. Matrycuja komunikowanie publiczne, co ma również wpływ na kształt wypowiedzi prywatnych. I jeszcze jedna sprawa, która wydaje się istotna: wszelkie odmiany gatunku wypowiedzi wodzowskiej, replikowane i przytaczane przez media, wyznaczają w dzisiejszej kulturze istotny obszar mowy żywej, uważanej dość powszechnie za zdominowaną przez znak graficzny (pisany) i obraz.

Abstract

ZBIGNIEW KLOCH University of Warsaw ORCID: 0000-0002-7832-0368

\section{CHIEF COMMAND'S VARIOUS KINDS OF RHETORIC A FEW REMARKS ON SELECTED CASES OF LEADER SPEECH}

The article is an attempt to define the role and genre property of various leader speeches in contemporary culture, their rhetoric functions and situational involvement. The comparative material are here fragments of so-called great speeches in history delivered by Hitler, Stalin, J. F. Kennedy, John Paul II, all of which serve as a starting point to refer to the speeches of contemporary politicians-Donald Tusk and Jarosław Kaczyński. The essay also includes the communicational practices of the Fascism (Language of the Third Reich) and the Polish variant of newspeak elaborated on by Michał Głowińskithe leader's binding mode of communication with the society in the time of the Polish People's Republic. Leader speeches is an applied literary genre, deeply involved into a situation, and changeable according to the political culture which the speaker represents. Such speeches, both the old and the contemporary ones, create the patterns of political speaking and strengthen some kind of rhetoric strategies. Additionally, they mark an important space of living speech quite commonly regarded as determined by a graphic (written) sign and an image.

na stronie: https://wiadomosci.onet.pl (data dostępu: 22 X 2018). Dodam, że prezes mówił o sukcesie wyborczym swojej partii. 